Yaroslav Slutskyi, PhD (Pedagogy), Doctoral Stud. Donbas State College of Technology and Management, Toretsk, Ukraine Donbas State Pedagogical University, Slov'yansk, Ukraine

\title{
THE ESSENCE OF THE SOCIAL AND PEDAGOGICAL PRINCIPLES FOR ACCOMPANYING FOREIGN STUDENTS
}

\begin{abstract}
The article researches the impact of adaptation principles on drawing up the effective preparatory system. The importance of applying the principles for the analytical activities implementation in the social and pedagogical process for accompanying a foreign student is revealed. The significance of principles for the renovation of the preparatory program is considered. It is determined that the adaptation principles, with timely practical application, contribute to the creation and development of relationships between all components of the process for accompanying a foreign student, which makes it possible for the system to emerge.
\end{abstract}

Keywords: adaptation training, acculturation skills, internationalization of education, inter-cultural interaction, accompanying system, social and cultural environment.

Introduction. The processes of education internationalization are among the main components of globalization changes in recent decades. The problems caused by quarantine restrictions due to COVID-19 have somewhat complicated, but not stopped the development of relationships between educational institutions, relying on distance forms of interaction. Despite the fact that various conferences, symposia, publications of scientific journals, etc. are the most represented in the informative educational sphere, an important component of the education internationalization is working with foreign students, which requires not only effective campaigning activities, but also more complex actions related to work with the personal attributes of the student, namely performing social and pedagogical accompanying process. In this regard, constant work not only by the student but also by the consultant - a person who should assist the student in adaptation issues is of great importance.

The problems of the educational system of Ukraine in matters of qualitative adaptation of foreign students are dictated, first of all, by the short period of this direction development after the country has become an independent state. Therefore, it is important to research foreign experience of working with such students to further improve the domestic adaptation system. In this regard, along with the analysis of practical measures, it is required to perform a theoretical research of all elements that affect the social and pedagogical accompanying process, among which we highlight the accompanying principles.

The purpose of the article is to explore the social and pedagogical principles for accompanying foreign students; identify their impact on adaptation as a multilevel process.

Analysis of recent research and publications. An important aspect of the study is the direct conceptual framework, characterized by many scientists, including M. Ivanova (identified adaptation as a necessary condition for further activities of the individual), V. Korolinska (highlighted three levels of adaptation - physiological, psychological and social [Korolinskaja, 2011]), H. Shevelev, L. Kabanova, K. Mykhalchenko (noted the presence of several forms of adaptation process, namely maladjustment, passive and active adaptation), I. Kryvtsova (studied the psychological problems faced by a foreign student in performing social and pedagogical accompanying process), O. Kachyn'skyi (identified personal manifestations that play a decisive role in the adaptation process to the new social and cultural environment [Kachyn'skyi, 2018]), V. Yachmenova (concluded that there are objective reasons for regular renovation of the adaptation process [Yachmen'ova, 2007]) etc.

In its turn, the adaptation process causes the phenomenon of adaptability, which was considered in the works of A. Maksymovych, H. Khanaliiev, V. Fomin and others. At the same time, I. Maksymchuk concludes that adaptability is characterized mainly by reactionary changes to external factors that directly affect the individual.

Foreign researchers have also considered the problems associated with the students' adaptation process from certain national groups. For instance, K. Brisset, S. Safdar and K. Sabatier studied psychological and social and cultural training aspects of foreign students from Vietnam [Psychological and sociocultural adaptation..., 2010]. The studies of such scientists as K. Glass, E. Gomes, A. Urzua [Glass, Gomes \& Urzua, 2014], J. Lee [Lee \& Ciftci, 2014] were also devoted to this direction.

Due to the fact that the adaptation principles determine the effectiveness of various accompanying components, including the internal and external influence component, the studies of the already mentioned researchers are of interest, including E. Gomes, A. Urzua and K. Glass on the influence of social relationships on the adaptation process [Gomes, Urzua \& Glass, 2014].

The inter-cultural adaptation process in general can be traced in the works of such scientists as K. Wan, U. Chan [Wan \& Chan, 2017], K. Bowman [Bowman, 2015] and others.

Adaptation experience of other countries, in particular, the USA has been the subject of study by many researchers, including M. Tas [Tas, 2013].

The theoretical framework presented by scientists, and different types of classifications for adaptation and adaptability (including taking into account the national factor) are of fundamental importance in our research. However, as we can see, the issue of the principle importance in drawing up a social and pedagogical accompanying system for foreign students has not been properly studied that demonstrates the relevance of our work.

Presentation of the main positions. The system of training of foreign students requires effective interaction and management of all adaptation elements by both the consultant and the foreign student. As a result, there are appropriate accompanying principles, including: constant type adaptation, progressive, prospects, complex, operative, optimality, simplification, coherence, integrity, and efficiency principles.

Despite the fact that the foreign student being in another culture requires adaptation training, it should be borne in mind that if one pays attention only to the period of training, defined by the preparatory program, the primary adaptation skills will be formed and the individual will be able to perform inter-cultural interaction at a certain level. However, this level may not be enough, especially if we are talking about social interaction, which is characterized by slightly different aspects of interpersonal contact that are often not used in academic sphere. 
So, the acquired adaptation knowledge will not be able to fully comply with the social needs of a foreign student, so it is important to apply the constant type adaptation principle, when a foreign student participates in regular interpersonal contact with the representatives of other cultures, both in the academic (communication with group-mates, teachers, etc.) and social (communication with representatives of the host country, which may include home stay family members of the student) spheres. Moreover, the social environment is a flexible element, prone to constant change, in accordance with globalization, which requires the cultural patterns transformation, changing them to more relevant patterns for a specific period of time.

Thus, using regular adaptation, the foreign student gets the opportunity not only to understand social transformations, but also to adapt their previously acquired skills thereto, otherwise, they may be socially obsolete and not perform the function of providing effective inter-cultural interaction. In addition, regular adaptation contributes to a slower change in one's cultural patterns, which does not require further adaptation training, which will require participation due to the increasing number of social and cultural obstacles and errors associated with lack of adaptation flexibility. Thus, the selected principle is an important condition for the successful activity of a foreign student, because its observance should ensure the absence of requirement for adaptation retraining due to the constant change of social and cultural background.

Preparatory adaptation programs, even in the presence of indicators confirming their effectiveness, should not be static, that is why, according to E. Woods, L. Sklair and J. Goldthorpe, progressive principle plays an important role [Woods, 1907; Sklair, 1970; Goldthorpe, 2007, p. 56, 60]. Due to the fact that globalization has a regular and significant impact on the society of different countries, correspondingly, training shall also be renovated, otherwise, its effectiveness in terms of integrating the individual into the new social and cultural sphere will be significantly reduced. It is also necessary to consider and, if necessary, adopt the experience of social and pedagogical adaptation of foreign students, which is used in other countries. Thus, when using the experience of other countries in training foreign students in their own programs, there is an element of global progress in adaptation training programs.

It should also be noted that the requirement to change the strategy or methods of training foreign students is influenced by social reality, which involves paying special attention to the features of integration that society needs to interact with foreign students in a certain period of time. For example, modern adaptation requirements for the representatives of other countries provide the availability of such training for all students, regardless of their nationality, religion, etc. Thus, modern society requires the absence of discrimination elements on any grounds, including within the social and pedagogical accompanying process. It is also important to eliminate the effect of uneven adaptation, when some students have more opportunities for quality training, while others have mastered the theoretical material worse and received less practice. In this case, adaptation may be considered uneven and, consequently, ineffective in terms of mass, which will cause the separation of a certain number of foreign students from the society of the host country and the creation of national communities of intra-academic or university plan and therefore the inability of these community members to become part of the host country's society, which will cause further problems of the inter-cultural plan.

Also, when we talk about the progress of adaptation training, it is important to take into account such a modern requirement created by globalization as information technology, which has been the subject of research by such scientists as M. Maeers, N. Browne, E. Cooper [Maeers, Browne \& Cooper, 2000], J. Allen [Allen, 2000] and others. Thus, modern means of transmitting information, such as the Internet, provide the opportunity to use additional methods of adaptation training in two formats - face-to-face (which uses technology to visualize theoretical material as an aid in direct contact between the consultant and the foreign student with social and pedagogical accompanying process) and distance (provides an opportunity to replace face-to-face adaptation training, which can be used to provide additional material that is important to the student, but not relevant to the preparatory classes). Distance method can also be used during pre-adaptation training when the foreign student has not yet arrived in the country for studying. In this case, the use of modern information transmission technologies (including distance learning) is the only way of primary training.

An important principle that contributes to the study of prospects for the development of both the personality of the foreign student (within the framework of adaptation training) and society as a whole (both national and global), and leads to awareness of the need for changes in methodological training support, is the principle of prospects [Mamchur, 2011]. When studying the prospects, there is an opportunity to consider the features specific for society, which is affected by globalization effects (leading to changes in social consciousness) and, subsequently, requires the renovation of the preparatory components to prevent a decrease in adaptive efficiency. In general, the features that can be identified in the future consideration, have two main directions of their social impact, namely positive and negative. Thus, the positive features are manifested in the development of a globalized type society, open to representatives of other cultures and interested in the adaptation of foreign students to their cultural standards, as well as the adoption of cultural peculiarities of representatives from other countries. As for the negative factors, it is necessary to try to create obstacles for them, which will have a positive impact on the society of the host country and on the success of adaptation training of foreign students, because of the negative attitude towards foreigners, the unwillingness to cooperate with higher educational institutions and community counselling centres (which may be manifested, for example, in the refusal to provide accommodation to students from other countries), even a well-made adaptation will not be able to assist creating conditions for the full integration of the individual into the culture and society of the host country. Thus, the long-term consideration of adaptation and possible problems that may be associated with it is an important element that provides information assistance in establishing more effective preparatory process not only with foreign students but also with community members, for whom the higher educational institution conducts its activities.

When studying the features of social and pedagogical accompanying process in the system of higher education in other countries, one can identify many components that are used and regularly improved in order for this system to have effective indicators. Correspondingly, the work of such a number of elements causes the requirement to consider a complex principle, the main purpose of which is to draw up a relationship between all components of the accompanying system. In addition, it is important to understand that such interaction should take place at each stage of the preparatory process. That is, in the development of the adaptation program there are stages that help to structure 
the training and ensure the thematic delimitation of the whole process. Accordingly, the emerging stages also require the interaction of all accompanying elements for a foreign student, from the support of psychological and linguistic aspects to the implementation of prognostic actions and, if necessary, renovation of the developed program due to the changes in the inner essence of society. Therefore, the mutual work of all the outlined components at one particular stage and their separation at another one, will not allow to come to positive indicators in terms of student's training.

So, it is important to ensure the interaction of the accompanying components at all preparatory stages, which will ultimately cause the concept of interaction within the system of social and pedagogical accompanying process. It is important to note that to ensure and draw up such a connection, it is necessary to analyse all the factors that affect the accompanying system, regardless of their focus, which can have be both of positive and negative nature. Examples of such factors are the time factor (which is one of the most important because it determines how much time a foreign student can spend on preparatory activities before the lack of acculturation skills in the process of social and academic activities could have a negative impact).

In its turn, the time limits are directly dependent on the level of existing competencies of the foreign student. In other words, on the difference between the level of formed and absent (or insufficiently developed in theoretical or practical directions) skills; as well as a factor of psychological stability of the foreign student.

Psychological preparedness of the individual to interact with representatives of other cultures and encounter social and cultural difficulties is the basis for the success of adaptation training, because even with the use of quality training, but in the absence of psychological stability, the foreign student will not be able to effectively overcome the difficulties arising in communication, which will eventually cause the impossibility of acculturation and integration into the new environment.

It is important to understand that the speed of renovation of the social and pedagogical preparatory components for accompanying foreign students depends on the ultimate effectiveness in preventing the emergence of negative social and cultural manifestations, as well as ongoing work to address them. So, it is also possible to allocate the operational principle directed on fast carrying out the analysis of the adaptive preparatory activity, revealing of existing shortcomings or the problems arising during acculturation actions and creation of conditions for improvement of preparation programs.

Operability in working with foreign students plays a significant role, because in the absence of reaction to negative manifestations (a lack of understanding of the cultural peculiarities of the host country can be an example. In this regard, conflicts may arise in the future), the quality of the entire accompanying system may be doubtful. Therefore, consultants, as well as representatives of higher educational institutions, in identifying problems that arise in the interaction of a foreign student with representatives of the host country society in the linguistic, social and cultural or other directions should refer to the operational principle for fast response to the situation and the implementation of actions to eliminate negative acculturation manifestations (examples of such actions may be a repeated course of adaptation measures, conversations with the student to identify their personal opinion on existing problems, etc.). In case when the principle of operability is not applied, the existing difficulties will cause other problems, which will compromise the possibility of effective activities for foreign students in the academic and social spheres, that is, they will not be able to perform academic activities at a higher educational institution. Thus, the lack of operative work with a foreign student has a negative impact on the entire accompanying system.

It also stands to mention that the training program for each student must be individual depending on the available skills, the psychological stability level of the individual, the ability to quickly learn new theoretical material and the ability to apply it in practice, etc. In this regard, there is a principle of optimality, aimed at the individual work with each foreign student. Thus, even if there is information as for the student's identity, which includes the important information for the development of the preparatory program, it is necessary to predict several options for the development of preparatory events.

So, it is necessary to develop several versions of the program, the most optimal of which will later be used for adaptation, but at the beginning of the preparation stage it is important to have the possibility of accompanying process in different directions of adaptation. Therefore, the most effective method of preparation can be chosen after its beginning, while during the development of an individual plan it is important to consider several possible preparatory options. This principle is important due to the fact that optimality makes it possible to develop a preparatory program for a particular foreign student, which will take into account their individual abilities and available skills, as well as psychological indicators. Thus, it is possible to use the most effective version of the individual training, the purpose of which will not be the student's adaptation to the accompanying system, but the desire of the system to change and adjust to the indicators specific for the particular individual.

Due to the fact that the preparatory process consists of a large amount of theoretical content aimed at developing the most necessary competencies for a foreign student, assimilation of such amount of information may take some time, depending on the personal abilities of the individual. However, if adaptation training requires cutting the amount of time (this may be due to the requirement of developing at least basic inter-cultural skills for simple interpersonal interaction) it is necessary to cut the existing theoretical material without loss of important components. Therefore, it is required to apply the simplification principle, which is used to cut the material without losing its quality level. It should be noted that the main task of the consultant and the student, while cutting the preparatory material, is to maintain the effectiveness of the adaptation process. Bearing in mind that the accompanying system is an interconnected process, each component of which has a certain impact on others, simplification without prior analysis of the possible consequences may reduce the overall level of training quality.

Therefore, simplification should also take into account individual and psychological peculiarities of the individual and remove a particular material on their basis. For this purpose the analysis directed on revealing of features (specific for the certain individual) which can negatively affect adaptation at carrying out simplification is used. Thus, it is not possible to use the same models to simplify the adaptation material for all students representing different countries, nationalities, language groups, etc. Accordingly, the consultant must be acquainted with the peculiarities of the foreign student (which should be identified in the previous preparatory stages). So, the simplification of the preparatory material should be based on the characteristics of the student's individual.

It is important to understand that the adaptation of a foreign student is a multi-level process involving not only the 
student and the consultant, but also members of the community who require to interact with students from other countries and cultures due to their accommodation next to the higher educational institution. It is also necessary to take into account the important role of the country in accompanying the adaptation system development, including through the adoption of the necessary legal framework. Therefore, all relationships of this kind demonstrate the requirement to apply the principle of consistency, within which it is possible to carry out joint activities of all the system structural units of social and pedagogical accompanying process, including both internal components of the system and factors of an external direction. Thus, for the successful individual adaptation of a foreign student, it is important to work closely in different directions, which were presented by us in the form of Table 1.

Directions important for performing effective adaptation

Table 1

\begin{tabular}{|c|l|}
\hline Direction & \multicolumn{1}{|c|}{ The direction requirement for adaptation } \\
\hline Economic & $\begin{array}{l}\text { due to the fact that the lack of the necessary funding level for student training will cause the lack of opportunity to } \\
\text { develop program accompanying }\end{array}$ \\
\hline Regulatory & $\begin{array}{l}\text { because the adoption of the necessary legislation on the development and maintenance of the accompanying } \\
\text { system is one of the fundamental elements of effective development }\end{array}$ \\
\hline Social & $\begin{array}{l}\text { because the foreign student has to participate in the integration interaction processes with society, representatives } \\
\text { of the local community, etc. }\end{array}$ \\
\hline
\end{tabular}

To form links between directions mentioned, within the accompanying system the activities and initiatives aimed at carrying out adaptation actions in society should be organized, in other words, in practical interaction with the new social and cultural environment. However, it is necessary to understand that such measures should be relevant in adaptation matters for a student.

In addition, the required continuous improvement of the preparatory system for foreign students demonstrates the importance of applying two principles necessary for stability of the entire system of social and pedagogical accompanying process, including: the integrity principle (in case of errors occurred in the training program for students from other countries, the effectiveness of the whole system may be doubtful. Therefore, applying this principle, it is possible to prevent the imbalance of the entire accompanying system in case of problematic issues identification, which, in particular, may be caused by untimely renovation of the adaptation training program, which is required by a changing society. All components of the accompanying system must be closely interconnected, which will ensure the support of each component to others. Thus, the integrity of the system is formed, when even the impact of problematic situations can not violate it and cause inefficiency); principle of effectiveness (in case of the training system has received too high a level of negative impact of organizational and methodological problems and the integrity of the entire preparatory structure has been violated, there is a need to apply the principle of effectiveness, which allows the accompanying system even in case of the integrity violation to restore its preparatory functions in the shortest possible time, which minimizes the negative consequences for the adaptation of foreign students).

Conclusions. The social and pedagogical system for accompanying foreign students should include a set of specific principles that will create coherence and consistency of adaptation activities. The main objectives of these principles are:

- ensure the continuity of accompanying a foreign student regardless of changes in social and cultural directions;

- introduce innovations dictated by globalization changes in preparatory programs;

- identify positive and negative prospects of the adaptation process, which will make certain changes to the preparatory strategy at the right time;

- combine the existing components of the adaptation process into a single component that will make it possible to call this process a system;
- perform an operational analysis for the negative aspects of adaptation activities to overcome them to the point where such influence will reduce the effectiveness of training a foreign student

- determine the optimal strategy for adaptation development of the foreign student's individual;

- carry out transformational measures of theoretical preparatory content without losing its effectiveness;

- combine the probable influence of both internal (academic) and external (social) factors on a foreign student for successful adaptation in all necessary activities;

- restore the sequence of the prospect preparation program for a foreign student in case of unforeseen or erroneous displays in adaptation measures.

As a result, we can say that the principles of accompanying foreign students are important components that combine the preparatory process and the outlined longterm preparatory program into a single system that comply with the requirements and challenges of a society that regularly transforms. Insufficient application of one of the principles can negatively affect the entire preparatory strategy, so it is important to realize the importance of their regular or immediate application (depending on the purpose of the principle and the situation that has arisen during the adaptation process).

Further research on this issue can be aimed at studying other components of social and pedagogical accompanying process, which have fundamental importance for the existence of the adaptation system, namely functions. The works devoted to the practical application of the outlined adaptation principles during the preparation of foreign students on the example of foreign countries and Ukraine can also be considered promising.

\section{References}

Kachins'kij O. Social'no-kul'turna adaptacija studentiv (medichnih special'nostej) u procesi distancijnogo navchannja jak naukova problema / $\mathrm{O}$ Kachins'kij // Pedagogichni nauki: teorija, istorija, innovacijni tehnologiyi. 2018. - № 5(79). - S. 99-111.

Korolinskaja S.V. Nekotorye problemy adaptacii inostrannyh studentov anglijskogo otdelenija NFaU / S.V. Korolinskaja // Fizicheskoe vospitanie studentov. - 2011. - № 4. S. 48-51.

Mamchur L. Realizaciya pryncypu perspektyvnosti j nastupnosti u procesi formuvannya komunikatyvnoyi kompetentnosti uchniv pochatkovoyi ta osnovnoyi shkoly / L. I. Mamchur // Visnyk LNU im. T.Shevchenka. - 2011. № 15(226). - S. 18-25.

Yachmen"ova V. M. Identyfikaciya stijkosti diyal"nosti promyslovyx pidpryyemstv: monohrafiya / V. M. Yachmen"ova. - Simferopol" : Dolya, 2007. $-384 \mathrm{~s}$

Allen J. Information systems as technological innovation / J. Allen I/ Information Technology \& People. - 2000 - № 13(3). - P. 210-221.

Bowman K. D. Beyond orientation: Going the extra mile helps international students adjust to a new culture / K. D. Bowman // International Educator. 2015. - № 24. - P. 42-45. 
Glass C. R., Gómez E., Urzua A. Recreation, intercultural friendship, and international students' adaptation to college by region of origin / C. R. Glass,

E. Gómez, A. Urzua // International Journal of Intercultural Relations. - 2014 - № 42. - P. 104-117.

Goldthorpe J. Progress in Sociology: The Case of Social Mobility Research / John $\mathrm{H}$. Goldthorpe // Analyzing Inequality: Life Chances and Social Mobility in Comparative Perspective. - Stanford: Stanford University Press, 2007. - P. 56, 60.

Gomez E., Urzua A., Glass C. The impact of social networks and leisure on cultural adjustment / E. Gomez, A. Urzua, C. Glass // Journal of Park and Recreation Administration. - 2014. - № 32(1). - P. 7-25.

Lee J., Ciftci A Asian international students' socio-cultural adaptation: Influence of multicultural personality, assertiveness, academic self-efficacy, and social support / J. Lee, A. Ciftci // International Journal of Intercultural Relations. - 2014. - № 38. - P. 97-105.

Maeers M., Browne N., Cooper E. Pedagogically Appropriate Integration of Informational Technology in an Elementary Preservice Teacher Education
Program / M. Maeers, N. Browne, E. Cooper // Journal of Technology and Teacher Education - 2000 - № 8(3) - P. 219-229.

Psychological and sociocultural adaptation of university students in France: The case of Vietnamese international students / C. Brisset, S. Safdar, J. Lewis, C. Sabatier // International Journal of Intercultural Relations. - 2010. - № 34(4). - P. 413-426.

Sklair L. The Sociology of Progress / Leslie Sklair. - London: Routledge, 1970. $-288 \mathrm{p}$.

Tas M. Best practices in hosting international students in the U.S. / M. Tas // Cross-Cultural Communications. - 2013. - № 9(2). - P. 14-17.

Wan K. W., Chan W. Acculturation and cross-cultural adaptation: The moderating role of social support / R.W. Wan, W. Chan // International Journal of Intercultural Relations. - 2017. - № 59. - P. 19-30.

Woods E. Progress as a Sociological Concept / Erville Bartlett Woods // American Journal of Sociology - 1907 - Vol. 12 - № 6. - P. 779-821.

Надійшла до редколегії 20.05.21

Ярослав Слуцький, канд. пед. наук, докторант

Донбаський державний коледж технологій та управління, Торецьк, Україна

Донбаський державний педагогічний університет, Слов'янськ, Україна

\section{СУТНІСТЬ ПРИНЦИПІВ СОЦІАЛЬНО-ПЕДАГОГІЧНОГО СУПРОВОДУ ІНОЗЕМНИХ СТУДЕНТІВ}

Досліджено вплив адаптаційних принципів на вибудовування ефективної підготовчої системи, серед яких: принцип адаптації постійного типу, прогресивний принцип, принцип перспективності, комплексний, оперативний, принцип оптимальності, спрощення, узгодженості, цілісності, дієвості. Виявлено їхні сутнісні характеристики, а саме: проведення міжособистісної взаємодії академічного та соціального плану (принцип адаптації постійного типу); сприяння трансформаційним змінам у програмах підготовки іноземних студентів у зв'язку зі змінами міжнародного досвіду (прогресивний принцип); внесення змін у підготовчу стратегію згідно з результатами перспективного дослідження (принцип перспективності); вибудовування зв'язків між елементами системи адаптаційної підготовки іноземного студента (комплексний принцип); виявлення поточних та ймовірних проблемних проявів у системі адаптаційної підготовки (оперативний принцип); створення умов для можливості розробки індивідуальної програми підготовки іноземного студента (принцип оптимальності); редагування адаптаційного теоретичного матеріалу без втрати сутнісної складової (принцип спрощення); об'єднання всіх сфер, що впливають на іноземного студента задля досягнення адаптаційної мети (принцип узгодженості); забезпечення цілісності системи адаптаційної підготовки (принцип цілісності); відновлення системи адаптації у випадку виникнення проблемних ситуацій (принцип дієвості). Визначено роль регулярної адаптації, що характеризується забезпеченням постійного соціокультурного оновлення особистісних шаблонів (теоретичні знання) для можливості їхнього застосування та формування, таким чином, адаптаційної гнучкості (практична діяльність). Зазначено, що методики підготовки іноземних студентів можуть і повинні змінюватися залежно від потреб суспільства і трансформаційних змін, що виникають у ньому. Зауважено про запобігання нерівномірності адаптаційної підготовки, що може призвести до недоотримання знань між особистостями і, у підсумку, розбалансування академічної групи, де присутні іноземні студенти.

Ключові слова: адаптаційна підготовка, акультураційні навички, інтернаціоналізація освіти, міжкультурна взаємодія, система супроводу, соціокультурне середовище. 